scales of complexity; not only the individual, but also the group, the larger community, and the global. One of the challenges posed to sociology by this phenomenon is to explore how individual transformative experience may be connected with the global and under what conditions can transformations at larger social scales be said to be connected with the individual experience (Bajc 2012).

\title{
REFERENCES
}

Bajc, Vida. 2012. "Pilgrimage," in George Ritzer (ed.), Encyclopedia of Globalization. Oxford: Wiley-Blackwell.

Bajc, Vida. Forthcoming. Christian Pilgrimage in Jerusalem: Performing Social Realities. Chicago, IL: University of Chicago Press.

Bowditch, Rachel. 2008. On the Edge of Utopia. Performance and Ritual at Burning Man. Chicago, IL: University of Chicago Press.

Coleman, Simon, and John Elsner. 1995. Pilgrimage: Past and Present in the World Religions. Cambridge, MA: Harvard University Press.

Csordas, Thomas. 1997. The Sacred Self: A Cultural Phenomenology of Charismatic Healing. Berkeley, CA: University of California Press.

Eade, John, and Michael Sallnow(eds.). 1991. Contesting the Sacred: The Anthropology of Christian Pilgrimage. London: Routledge.

Huber, Toni. 2008. The Holy Land Reborn. Pilgrimage and the Tibetan Reinvention of Buddhist India. Chicago, IL: University of Chicago Press.

Kelner, Shaul. 2010. Tours that Bind: Diaspora, Pilgrimage, and Israeli Birthright Tourism. New York: New York University Press.

Margry, Peter Jan (ed.). 2008. Shrines and Pilgrimage in the Modern World. New Itineraries into the Sacred. Chicago, IL: University of Chicago Press.

Smelser, Neil. 2009. The Odyssey Experience: Physical, Social, Psychological, and Spiritual Journeys. Berkeley, CA: University of California Press.

Swatos, William, and Luigi Tomasi(eds.). 2002. From Medieval Pilgrimage to Religious Tourism: The Social and Cultural Economics of Piety. Westport, CT: Praeger.

Thal, Sarah. 2005. Rearranging the Landscape of the Gods. The Politics of a Pilgrimage Site in Japan, 1573-1912. Chicago, IL: University of Chicago Press.

Turner, Victor. 1973. "The Center Out There: Pilgrim's Goal," History of Religions 12(3): 191-230.

Turner, Victor. 1974. "Pilgrimage and Communitas," Studia Missionalia 23: 305-327.

Van Gennep, Arnold. 1960. The Rites of Passage. London: Routledge \& Kegan Paul (Orig. pub. 1909).

\section{The Moral Sociology of Viviana Zelizer}

\section{Marion Fourcade ${ }^{1}$}

Economic Lives. Zelizer, Viviana. Princeton, NJ: Princeton University Press, 2011.

Nothing is harder than to write about a scholar who not only has commanding authority over one's field, but who is also, to this day, such a

1 Department of Sociology, University of California at Berkeley, Barrows Hall 410, Berkeley, California 94720-1980 and Max Planck-Sciences-PO Center, 28 rue des Saints-Pères, 75007 Paris, France; e-mail: marion.fourcade@gmail.com. 
determining influence in one's own intellectual trajectory. Viviana Zelizer is both to me, and much more. I first came across her work in 1992, in a French translation of an article on the adoption market she published in Actes de la Recherche en Sciences Sociales, the review founded and edited by Pierre Bourdieu. She was probably well established in the United States by then, but I was an ignorant French graduate student, and I found the piece liberating. By taking concrete transactions as its unit of analysis rather than some putative market, or market actors, Zelizer's article opened up a path for others to do something new. By historicizing the economic rationality of such transactions, it was in effect demonstrating (in a devastatingly effective way) the relevance of social context. Zelizer did not need to articulate the critique of economics' universalistic pretensions directly: she could just go quietly about demonstrating empirically the pertinence of such a critique, pointing to the existence of economic processes in unusual places, and looking at them through a lens that had been largely ignored up to that point - the cultural history of everyday practices and rituals.

Since then, the field of economic sociology has institutionalized, expanded, multiplied, but Zelizer's work has not lost its appeal. Her place remains unique and remarkably uncontroversial in an intellectual community that often harbors conflict. There is, in fact, somewhat of a paradox between her centrality to the field's self-understanding (the economic sociology book prize is named after her) and her work's great distance from the modal contributions in economic sociology, which edge closer to the world of business and management (Convert and Heilbron, 2007). Confirming this paradox, Zelizer writes in Economic Lives (p. xi) that her intellectual trajectory (as captured by this book) is a "shadow history" of economic sociology - a subterraneous, somewhat contrary undercurrent whose effects have been both undeniable yet never overwhelming. As a field, economic sociology has indeed remained steadfastly dominated by a focus on the production, and visible, side of the economy, but Zelizer's substantive research and eloquent critiques (see, e.g., Chapter 19 in this book) have also spurred and converged with the interest in consumption found in cultural studies and elsewhere. Following the path opened by Pricing the Priceless Child (1994), economic sociology now harbors a healthy amount of research on nonstandard "markets" (e.g., biomedical markets); more recently, The Purchase of Intimacy (2005) contributed to relocate the subjects of domestic labor, care, and sex more firmly within the legitimate purview of economic sociology, away from their traditionally more peripheral place in gender studies.

With its coverage of more than 30 years of sustained scholarship, Economic Lives reveals, in a condensed form, Zelizer's brilliant craftsmanship in knitting together innovative narratives about the ceaseless interplay between money and social relations, means and meaning, objective and subjective, material and symbolic. As a collection of articles that retrace the intellectual trajectory of a prolific and deeply original scholar, the book beautifully displays the consistency of Zelizer's method of exposition over time, and 
underscores why we continue to need her direction to sustain the evolution of the field with original questions and examples that do not fit expectations. As in her other books, nearly every chapter here opens with ingeniously crafted vignettes drawn from court cases, idiosyncratic stories clipped from old newspapers and magazines, or examples drawn from a wide range of academic publications (Zelizer is also an extraordinary reader of other people's work). Consider: "On March 14, 1895, the Boston Evening Transcript stated" (Chapter 2); "The Baby M deal would astonish any nineteenth-century baby trader" (Chapter 3); "American novelist Frederic Turen recalls scenes from his New York childhood during World War II" (Chapter 4); "On Rossell Island, a small, traditional community in the southwestern Pacific, the gender of money was tangibly identified" (Chapter 5); "During the late 1990s, John Bowe, Marisa Bowe, Sabin Streeter and their collaborators were interviewing Americans about their work" (Chapter 8); "In March 2005, a remarkable case stirred the courts and press of Florida before becoming a national cause célèbre" (Chapter 9); "Here are four vignettes of children's economic activities" (Chapter 11); "When Paul Wolfowitz took over as head of the World Bank, he faced a delicate problem" (Chapter 12); "Here is how an Austrian woman reports her response to being paid by Caritas, a Roman Catholic charity, for taking care of her mother-in-law" (Chapter 13); "In October 2006, icon pop singer Madonna attracted international headlines by adopting David Banda" (Chapter 14); and so forth.

There is nothing futile or arbitrary in this seemingly chaotic list. Rather, the marshaling of a broad range of concrete cases allows Zelizer to draw skillfully from the never-ending play of human interests, emotions, and relations, and consider the finest nuances in people's motives and actions. The purpose is always to firmly demonstrate how the analytical question-the interweaving of social and monetary relations - is not only grounded in, but actually emerges from, everyday puzzles people and institutions face in real life. Through this extraordinarily varied, often captivating, and painstakingly collected material, Zelizer has become the master chronicler of how individuals live their (connected) economic lives.

But while her narrative strategy has remained largely unchanged over time, her analytical focus has visibly moved. The first shift, clearly performed in Economic Lives, is from cultural history to microsociological analysis; from a quasi-Durkheimian study of long-term historical change in Part I of the book to a quasi-Simmelian study of the complex interplay between the individual and the collective in Part II; from the large institutions that organize people's lives to the personal exchanges that give them meaning - and that always defy simple models and generalizations. Morals and Markets (1979), Pricing the Priceless Child, and some parts of The Social Meaning of Money (1997) had a clear historical thesis. Zelizer gave us to read and understand momentous cultural changes (in gender relations, family structure, parent-children relations) through the substantive transformation of modes of payment, values, and earmarking processes over time. However, her more recent 
works - and the later chapters in Economic Lives - are less explicit and more muted about their historical implications: while this avoidance is in part the product of a personal trajectory away from history and toward sociology's core, it also says something about the difficulty of describing the direction of history in today's decentralized, flexible world. ${ }^{2}$

The second shift is from objects (death, children, money, intimacy) (Parts I-III) to concepts (differentiated ties, connected lives, good matches, and circuits of commerce in Parts V-VI, relational sociology in Zelizer [2012]), and manifests Zelizer's growing ambition to articulate a properly theoretical agenda for economic sociology. One of her greatest analytical contributions is to have made us painfully aware of how hard it is to avoid the pitfalls of what she calls the "nothing but" and the "hostile worlds" approaches to intimate transactions. "Nothing but" mistakes are typical of academics, who often reduce intimate economic arrangements to the one single dimension they have expertise on (e.g., self-interest, power, culture) - in some ways, this is what Pierre Bourdieu (1990) calls the "scholastic fallacy": taking one's intellectualized world for "the" world. "Hostile-worlds" approaches, on the other hand, refer to the analytical and prescriptive mistake of considering that personal relations and money are radically incommensurable and should not be allowed to mix. But fears of commodification and pollution through money are deeply misguided, Zelizer argues: empirically, life is both more complex and less clearcut than that: people contest these boundaries all the time in their everyday lives. Maintaining normative distinctions between personal relations and money at all costs leads to all kinds of contradictions and, often, to bad policies. $^{3}$ Money, Zelizer reminds us time and again, does not dry up social ties. Rather, it organizes them and reveals their nature.

Zelizer offers her vocabulary of "connected lives" to capture the fluid, constructed-in-the-relationship nature of intimate economic transactions. Likewise, the concept of "differentiated ties" modernizes, in a way, the old sociology of roles by acknowledging how "culturally-embedded, problem-solving people" (p. 336) develop different but stable personas depending on the form and content of the intimate transactions they carry out. She develops the notion of "circuits of commerce" as a new, more pragmatic take on network relations. Circuits, however, edge close to actor-network theory by incorporating material objects (modes of payments, in the form of tender, goods, or services) and motives into an understanding of how people connect to one another. The concepts of "earmarking," so central to The Social Meaning of Money, and that, more recent, of "good matches" point to a form of intentionality in these processes, sometimes habitual and pragmatic, sometimes

${ }^{2}$ As William Sewell Jr. (2005) has beautifully argued, modern historians' and sociologists' attention to the fleeting, the variable, and the contingent is also historically situated, a product of a less structural vision and a post-Fordist, neoliberalized economy.

3 Perhaps owing to her connections to prescriptive legal scholars and economists, Zelizer occasionally offers practical guidance in this book, for instance providing recommendations to corporations seeking to develop policies dealing with intimate relations at work. 
self-conscious and strategic. These concepts help show how people and institutions work hard to find means of payments that are suitable and appropriate to the relationships they are deciding on. Together they form a theoretical stance that is very consistent with the core tradition in U.S. sociology, from pragmatism to interactionism, but it also softly and syncretically incorporates a much wider array of insights from a remarkably broad range of scholarship. ${ }^{4}$

This theoretical stance inevitably raises the question of where people obtain their nearly instinctive knowledge about the "good matches" they habitually make between modes of payments and personal relations - that is, matches that "sustain the relationship" and "get the economic work done." It is often silent about bad matches - the gaffes, faux-pas, and calls to order that Erving Goffman (1959) studied in another context. So where is, to use Goffman's words again, the "institutional order" that keeps people in line behind the "interaction order"? The enormously involved cultural work that people do around their personal relations is a powerful reminder that individuals differentiate because they (and their personal relations) are themselves differentiated socially: by class, gender, age, race, and the like. Hence the form that people's expressive economic transactions take is necessarily articulated with their location in a social structure. As Zelizer suggests, the differentiated modes of payment of a prostitute, a mistress, or a wife certainly arise out of, but also contributes to, the reproduction of a certain kind of gender order.

Zelizer is well aware that the systematic differentiation of relations and situational negotiations necessarily brings the analytical focus back on to social hierarchies, inequalities, and power relations. In fact, she conceives of her own approach as a bridge between the cultural and the sociostructural critiques of economics: "If the cultural alternative breaks out of the accepted instrumental paradigm, it falls into a different theoretical trap by overly subjectivizing the reality of the market. The market is indeed a cultural construct, but it is not only that. Reducing the market to an abstract set of meanings excludes the material, institutional and social reality of economic life. ... The cultural approach thus needs a better connection to class systems, family structure, gender, age and other such structural factors" (2011:375).

In that sense, the subtitle of Economic Lives ("How Culture Shapes the Economy") does not quite do justice to the analytical vision of its author. The jacket adds: "Economic Lives shows how shared cultural understandings and interpersonal relations shape everyday economic activities." This metaphor - shaping - perhaps undersells the true contribution of a scholar who has so effectively contested the conceptual divide between "culture" and "economy" in her own empirical inquiries. Its directionality - from culture to economy-is also unexpected for a contributor to Callon's (1998) The Laws of the

${ }^{4}$ The affinity with the work of Pierre Bourdieu, who like her establishes a close correspondence between the symbolic and the material sides of people's actions, is particularly obvious. 
Market volume, which argued for a reverse causality. ${ }^{5}$ Finally, calling on "culture" in the final instance is essential, but as Zelizer's own work suggests, it is also incomplete. Essential because, yes, culture is exactly what the institutional order behind the interaction order is about: shared understandings and relational habits people are socialized into and that largely guide their sense of what is, and what is not, a "good match." Incomplete because if people produce meanings through the symbolic use of goods and money, they (to paraphrase Karl Marx) do so out of circumstances not of their own choosing: the institutional order they navigate and negotiate in their everyday economic transactions comes powerfully structured, by existing patterns of social relations, and by formal organizations - most notably the court system, which provides the bulk of the cases Zelizer studied.

The "multiple markets" and "multiple monies" are not only differentiated horizontally; they are also sharply differentiated vertically, through moral distinctions between more or less worthy kinds of people, and the material implementation of moralizing and disciplining intentions (see, e.g., the study of women's household money in Chapter 5). Like Durkheim's, Zelizer's sociology is thus, ultimately, a sociology of morality, and the reference here is not simply to ethics (notwithstanding Economic Lives' last chapter, on "Ethics in the Economy"), but to the moral constitution of individuals through the bonds that tie them to other individuals (this is instead, what Zelizer [2012] is now calling a "relational" perspective). This sociology is generally concerned with how people, working through institutions (and sometimes against them), and using symbolic-material distinctions that signal moral commitments and assignments of worth, draw boundaries and connections between themselves and others, us and them, in their effort to constitute both as moral entities. But the economic angle was always a deeply original point of entry into this analytical project, and Zelizer has managed to renew its fruitfulness several times, turning people's economic lives into the gift that keeps on giving. This is why, perhaps, her work still reigns supreme in the description and analysis of the careful economic strategies individuals anxiously deploy to find meaning and a moral ground. And it might well continue to do so, we can only hope, for many years to come.

\section{REFERENCES}

Bourdieu, Pierre. 1990. “The Scholastic Point of View,” Cultural Anthropology 5(4): 380-391.

Convert, Bernard, and Johan Heilbron. 2007. "Where Did the New Economic Sociology Come From?" Theory and Society 36(1): 31-54.

Callon, Michel (ed.). 2008. The Laws of the Markets. Princeton, NJ: Princeton University Press.

Goffman, Erving. 1959. The Presentation of Self in Everyday Life. New York: Anchor Books.

Sewell Jr, William H. 2005. "The Political Unconscious of Social and Political History or the Confessions of a Former Quantitative Historian," in George Steinmetz (ed.), The Politics of

5 In her own chapter in that volume, Zelizer herself tells very precisely how people define or transform their social relations through the manipulation of payment systems. 
Method in the Human Sciences: Positivism and Its Epistemological Others: pp. 173-206. Durham, NC: Duke University Press.

Zelizer, Viviana. 1979. Morals and Markets. The Development of Life Insurance in the United States. New York: Columbia University Press.

Zelizer, Viviana. 1994. Pricing the Priceless Child: The Changing Social Value of Children. Princeton, NJ: Princeton University Press.

Zelizer, Viviana. 1997. The Social Meaning of Money: Pin Money, Paychecks, Poor Relief, and Other Currencies. Princeton, NJ: Princeton University Press.

Zelizer, Viviana. 2005. The Purchase of Intimacy. Princeton, NJ: Princeton University Press.

Zelizer, Viviana. 2012. "How I Became a Relational Economic Sociologist and What Does That Mean?" Politics and Society forthcoming. 